\title{
Performer, Reporter, and Marketer: Three Different Local Parliament Faces on Social Media
}

\author{
Zailani Surya Marpaung ${ }^{1}$ \\ Anang Dwi Santoso ${ }^{2}$
}

\begin{abstract}
Indonesian local parliaments have an image as a corrupt, closed, outdated, and unreachable institution in the public's eyes. However, the parliaments have never tried to more actively developing policies which encourage active community participation. The recent adoption of social media by local parliaments seems to be a sign of the parliament's willingness to encourage greater community contributions. However, little can be understood about the implications of these activities. Moreover, whether social media contributes significantly to community participation in local parliaments. The purpose of this study is to explore the use of social media by local parliaments. This study employed qualitative multiple case studies by conducting a content analysis on Facebook and Twitter in four local parliaments. This study found three faces of local parliaments on social media which are performers, reporters, and marketers. In general, there has been a willingness of local parliaments to become more transparent and participatory institutions. Nevertheless, the massive adoption of social media to promote more participatory democratic practices was conducted half-heartedly by the local parliaments. Practically, if local parliaments want to use social media to enchance their image, they must publish content that promotes openness such as online assembly and educative information.
\end{abstract}

\section{Keywords:}

local parliament; social media; public engagement

\section{Introduction}

Local parliaments are central decisionmaking institutions in the local democratic system. Local parliaments have several important functions such as setting budgets, deciding policies, and defining legal norms in society (Holmberg \& Rothstein, 2017). Therefore, the trust in the local parliament must be maintained, one of which is by increasing transparency, accountability, and public participation. Unfortunately, over the past few decades, public confidence in the local parliament has declined and on the other hand, they did not make significant efforts to develop a mechanism for public involvement in policy formulation (Grissom \& Harrington, 2013; Leston-Bandeira \& Bender, 2013). Therefore, local parliaments have an image as an institution which is closed, ancient, corrupt, and not easily accessed (Doro \& Kufakurinani, 2018; Hudaya, Smark, Watts, \& Silaen, 2015; Tomsa, 2014).

On the other hand, the recent emergence of social media has attracted the attention of

\footnotetext{
${ }^{1}$ Department of Public Administration, Faculty of Social and Political Sciences, Universitas Sriwijaya. Email: zailanisuryamarpaung@fisip.unsri.ac.id

${ }^{2}$ Department of Public Administration, Faculty of Social and Political Sciences, Universitas Sriwijaya.

Email: anangdwi@fisip.unsri.ac.id
} 
government such as local parliaments to adopt social media to increase public participation. Social media promises various benefits such as increasing transparency and accountability (Bertot, Jaeger, \& Grimes, 2010; Bertot, Jaeger, \& Hansen, 2012; Bonsón, Torres, Royo, \& Flores, 2012; Chun, Shulman, Sandoval, \& Hovy, 2010), increasing community participation in policy-making (Bertot, Jaeger and Grimes, 2010; Chun et al., 2010; dan Bonsón et al., 2012), and improving the quality of public services (Bonsón et al., 2012; Picazo-vela, Gutiérrezmartínez, \& Luna-reyes, 2012). Therefore, for the government, social media is more than a communication channel. Social media can facilitate community participation through the creation and maintenance of interactions and relations between government and society (Nica, Popescu, Nicolaescu, \& Constantin, 2014).

Local parliaments try to keep up with the times by developing strategies to promote public participation through the adoption of current technologies such as online petitions, websites, and social media (Hazel, Bourke, \& Worthy, 2012; Inman \& Inman, 2012, p. 120; Lusoli, Ward, \& Gibson, 2005; Macintosh, Adams, Whyte, \& Johnston, 2008; Missingham, 2011; Sæbø, Flak, \& Sein, 2011). Social media for local parliaments is a space which gives voice to the community and allows them access to valuable information. Social media encourages a shift from traditional media in presenting civic engagement and collective action. Moreover, individuals have more access and direct influence in the world of politics and decision making at the local level (Majumdar, 2017). Therefore, local parliaments can be public institutions which are more transparent, accountable, and able to encourage greater community involvement by using social media. Building good relations between local parliaments and citizens is an important dimension in understanding parliament and its role in the political system (Holmberg,
Lindberg, \& Svensson, 2017). Furthermore, parliamentary and community relations have received greater attention over the past few decades, especially due to the development of new media and reactions to political apathy trends (Leston-Bandeira \& Bender, 2013).

Meanwhile, research exploring the adoption of social media by local parliaments is still limited. Several studies have tried to analyze several contemporary forms of public participation such as petitions and websites (Leston-Bandeira \& Bender, 2013; Macintosh et al., 2008; Missingham, 2011). Studies which analyze the use of web 2.0 adoption by local parliaments tend to focus on politicians, political parties, parliamentarians as individuals, rather than institutions (Aldrich \& Ono, 2016; Lee \& Shin, 2012; Okura \& Kaigo, 2016; Sobaci \& Karkin, 2013). Also, the researchers analyzed the utilization of social media more by the executive rather than the legislative body (Bolívar, 2016, p. 14; Majumdar, 2017; Santoso, 2019).

This study focuses on the official accounts of local parliamentary social media such as Facebook and Twitter. Specifically, this research seeks to evaluate to what extent local parliamentarians use social media to foster government participation. Moreover, this study also tests the significance of the initiative, especially to see whether the efforts made have been able to increase public involvement which is still not yet known. This analysis focuses on four local parliaments which are Banten's Regional House of Representatives, West Java's Regional House of Representatives, DKI Jakarta's Regional House of Representatives, and Special Region of Yogyakarta's Regional House of Representatives.

The following section in this paper is a literature review on the benefits of social media in strengthening public engagement, parliamentary efforts to respond to developments in information and communication technology, and how social media may strengthen local 
democracy. After that, the research method which contains the selection of research locations, data collection, and data analysis. The research findings and discussion will be presented later. The final part of this paper is a closure which contains conclusions, weakness of research, and recommendations for further research.

\section{Strengthening Public Engagement through Social Media}

Public engagement is a term with various meanings. This concept refers to a concept of involvement which will eventually result in participation though not necessarily real participation. The simplest forms of public involvement are very diverse, ranging from receiving information to actual participation. Several experts have tried to explain the concept of public engagement (Arnstein, 1969; Carman, 2010; Curtin \& Meijer, 2006; LestonBandeira \& Bender, 2013). Arnstein with the ladder of citizen participation concept tries to explain about the degree of public participation from manipulation by the government to community control of policy. Then, Carman (2010) tries to classify the system of public involvement in the legislative process which consists of providing information to the public up to the integration of the community in the policy-making process. Next, (LestonBandeira \& Bender, 2013) who develops ideas about providing information which consists of passively receiving information, understanding information and identifying the relevance of information with the community in daily life. Last is (Curtin \& Meijer, 2006) who tries to classify the differences between thick transparencies and thin transparencies. Thick transparency is the provision of more substantive and effective access to information accompanied by efforts to encourage the public to receive and understand information.

The discussion of the potential of social media to strengthen public engagement was initiated by Dalton's (2008) study which found that ICTs were an important means of overcoming public distrust. Social media have the ability to establish new connections and reinforce current excellent relations in the context of relations between parliament and citizens. Social media is a channel of direct communication between members of parliament and those they represent, as well as means to encourage the availability of information for the community. Avery \& Graham (2013) in their study found that key elements of social media provide a mechanism for the process of accountability between the represented, representatives, and government.

The social media can also offer parliamentary visibility, in particular in a political system that distances parliamentarians from those they represent (Leston-Bandeira \& Bender, 2013). Social media can encourage the decision-making process to be seen by the public (Williamson \& Ruming, 2017). Therefore, social media is a powerful tool for creating good relations between parliament and society. The emergence of social media, particularly, may increase communication and input capacity from the community.

On the other hand, social media brings several challenges to be anticipated. Fundamentally, social media broaden the relations between parliamentarians and those represented by them into three different channels like representation in individuals, party groups, and parliament (Swigger, 2017). Each of these political actors has different potential and use in social media. Parliamentary institutions encounter various difficulties in adopting social media compared to individual and party group representatives. This is because the parliament has two responsibilities to uphold democratic values and provide space for people to make decisions (Ellison \& Hardey, 2014a). Then, parliament must become an impartial and apolitical institution when delivering certain content. 
Another challenge is that parliament has a complex process which results in the slow adoption of social media. Compared to individual representatives and party groups who are more flexible (Francoli \& Ward, 2008), parliament has many limitations which encourage a slowdown in social media adoption. The presence of social media will provide equal opportunities for those three entities. However, barriers to social media adoption which range from resources to electoral systems may make it difficult for parliament to effectively use social media. Particularly, if the party is the main political actor who determines the distribution of resources in fulfilling the mandate of parliament.

Parliament is a closed organisation because it concerns authority, decision-making, conciliation of interests and conflict resolution. Moreover, social media offers a variety of features which may drive the parliament to be an open and accountable organization for the community, which is a big step towards getting greater public participation (D. F. Norris \& Reddick, 2013). By using social media, the community will be more easily involved because parliament is more accessible. Moreover, parliamentary transparency will encourage public involvement because of the availability of information, especially in the decision-making process.

\section{Parliament in the Digital Era}

Social media has become the main means for parliament to inform its activities to the community. These efforts are the first step to achieve the expected level of transparency and accountability. The parliament can play its role in the legitimacy of political system through the provision of educational resources and information on the general political system and, in particular, on the role of parliament by using social media.

Online petitions, websites, social media, and other online platforms have been used in recent years by governments and nongovernment actors to encourage citizen engagement and increase the database and overall legitimacy of democracy from the regulation-making process (Joshi \& Rosenfield, 2013). The Parliament can take advantage of information crowdsourced, gathering citizen narratives, public consultations and expert knowledge by means of these various media.

The initiative for community involvement could enrich fresh legislative initiatives and enhance the performance and confidence of the society in the government (Leston-Bandeira, 2009). Social media facilitates the process of mobilizing people and networks to participate. In the digital age, the public is invited to express views on different topics and receive direct reactions from other members of the society.

Several researchers have explained the benefits of using the website by parliament. For example, Norris (2004) found that parliamentary websites may contribute positively to the three classic approaches in democracy by strengthening community interaction with parliament and providing access to social movements, networks groups, and civic organizations. Moreover, parliamentary websites may increase government transparency and the availability of information which can be accessed by the public. Parliamentary websites enable people to be more active and participatory in the formulation of public policies (Norris, 2004). The parliamentary website can support the existence of deliberate democracy by facilitating the process of communications, deliberation and collaboration between citizens (Hartz-Karp \& Briand, 2009) to achieve collective decisions which support the common good.

Another effort to increase public participation is through online petitions. An online petition is a participative tool used by official and unofficial players in e-democracy (Macintosh et al., 2008). An online petition is 
an informal instrument which use a bottom-up approach to mobilize communities which aims to encourage the government to take certain actions (Lindner \& Riehm, 2011). Moreover, online petitions try not only to voice opinions but also to encourage the making of necessary policies. The Ranchordás study (2017) found that online petitions represent a way to promote democratic participation, adopt policies to community needs and improve decisionmaking quality. Online petitions promote more than argument, but also inclusiveness, interaction and readiness to be convinced and to alter the current arguments. Community participation initiatives like online petitions are a source not only of social knowledge, but also an information source on local issues. Online petitions offer various benefits such as reducing costs derived from the use of efficient technology, rationalizing the process and increasing trust and transparency (Ranchordás, 2017).

\section{Social Media and Local Democracy}

Local government is the level of government closest to the community because it provides services which have a direct impact on the community such as the provision of education services, libraries, parks, road maintenance, etc. therefore, the local government is the government which directly interacts and serves the community (Hand \& Ching, 2011). Local governments must be in the same room as the society for information, service, and communication. (Fan, 2016; Scott, 2006) and social media platform is one of these platforms (Mergel, 2013). Therefore, the local parliament needs to present and not to be passive spectators.

The main advantage of social media is that the use of this media does not require specific technical skills and allows individuals to produce content and interact with other users (Kaplan \& Haenlein, 2010). Social media has been widely used at relatively low cost but offers an opportunity for the government to communicate with the community (Reddick, Chatfield, \& Ojo, 2017). The community may receive updates and information in real-time which is direct and directed (Bonsón et al., 2012). Moreover, communities may use their resources to build more symmetrical communication patterns and monitor government activities.

In the previous age, there were no options for politicians, parliamentarians and governments but to interact with the public using mass media (Anderson \& Mcleod, 2004). The community has a small opportunity to contribute to the realm of communication with the government, parliament and government agencies (Ranchordás, 2017). Recently, changes in the dynamics of political communication have made practitioners and academics consider the way they think and examine the practices of local citizenship. Communities actively involved are increasingly considered important for the transition from top-down to bottom-up government. Then, this encourages the awareness of the government to make room for public participation through collaboration and consultation in decision making.

The nature of a communication connection between leaders and the public is under constant change in the present communications setting characterized by the advent of multiple types of social media, an increase in online interactivity, and a fresh opportunity for citizens ' journalism (Aldrich \& Ono, 2016; Avery \& Graham, 2013). This era has been marked by the increasing possibility for the government including the executive and legislative to communicate directly with the public through various media such as websites, e-mail, and social media such as Facebook, Instagram, and Twitter. The initial aim of these initiatives is to make it easier for the public to engage in political issues (Chun et al., 2010).

Communication technologies such as social media, nowadays, move by being used to build dialogical and interactive communication 
and enable bridges of communication between the community and its representation(Firmstone \& Coleman, 2015). Such practices still leave many unanswered questions including the increasing relationship of communication and the consequences for the quality of community participation. In particular, it is necessary to explore the role of social media in the relation between people and political organizations seeking to motivate people to participate. Unfortunately, most studies of social media contributions to citizen participation focus on their impacts on citizen behaviour (Gennaro, 2006), the use of social media by politicians as individuals (Firmstone \& Coleman, 2015) or by political parties as collective bodies. Fewer studies have investigated how citizens are engaged in local parliamentary strategies.

In the implementation, parliament increasingly hopes for community engagement in the formation of local policies and holds local representatives accountable through interactive dialogue. Moreover, the local parliament notices that the community is increasingly aware of the meaning of their involvement. As stated by (Firmstone \& Coleman, 2015), people may become producers of information and opinions which are individually and collectively organized through social media. Furthermore, social media allows the community to be content contributors. Finally, digital activities on various social media may increase community contributions to become news resources, and through the comments column in various online forums, the community may play an active role to voice their interests.

So far practitioners and researchers have still not agreed whether social media can strengthen local democracy. On one hand, social media is able to facilitate mass collaboration between individuals and groups which then becomes a source of innovation and new ideas in democratic practices (Ellison \& Hardey, 2014b; Reddick et al., 2017). Social media is also believed to be able to promote openness, accountability, and transparency, which contribute to strengthening democracy at the local level(Avery \& Graham, 2013; Heaselgrave \& Simmons, 2016; Mossberger, $\mathrm{Wu}$, \& Crawford, 2013)and new tools such as social media have the potential to improve interactions with citizens through dialogue. Citizens are most likely to participate at the local level (Berry, Portney and Thomson, 1993; Oates, 1972; Oakerson, 1999. On the other hand, social media is also able to encourage community polarization, for example with the existence of hoax news and fake news which is certainly dangerous for local democracy (Brummette, DiStaso, Vafeiadis, \& Messner, 2018).

\section{Methods}

This study utilizes a case study approach to understand complex and contemporary social factors (Yin, 2014). This study conducts a content analysis on Facebook and Twitter in several local parliaments such as Banten's Regional House of Representatives, West Java's Regional House of Representatives, DKI Jakarta's Regional House of Representatives, and Special Region of Yogyakarta's Regional House of Representatives.

\section{Selection of Case Study}

This study intends to take place on Java Island by considering the ICT Development Index which is higher than other islands (Ambardi et al., 2017). Java Island is an island which is relatively more developed in terms of infrastructure compared to other islands. Of the 6 provinces in Java, there are 4 provinces which are active on Facebook and Twitter such as Banten, DKI Jakarta, West Java, and DIY, which are designated as research locations. Meanwhile, the Provincial House of Representatives is chosen by considering the activeness on social media compared to regency/city House of Representatives so that the activities are more easily observed. 


\section{Data Collection}

While there are debates on the disadvantages and advantages of automatic and manual data collection (Gulati \& Williams, 2013), this study collected data from Facebook and Twitter using the automatic approach. This method requires caution to avoid analytical difficulties due to large data sizes. Driven by this challenge, researchers tried re-check the data taken automatically by comparing it with search results on both social media. Researchers collected data on Twitter and Facebook within three months (March-May 2019). Table 1 presents the collected Tweets and Posts.

Table 1.

The Collected Posts and Tweets

\begin{tabular}{|c|c|c|}
\hline Names & $\begin{array}{l}\text { Collected } \\
\text { Posts }\end{array}$ & $\begin{array}{l}\text { Collected } \\
\text { Tweets }\end{array}$ \\
\hline $\begin{array}{l}\text { Banten's House of } \\
\text { Representatives }\end{array}$ & 137 & 29 \\
\hline $\begin{array}{l}\text { Jakarta's House of } \\
\text { Representatives }\end{array}$ & 215 & 144 \\
\hline $\begin{array}{l}\text { West Java's House of } \\
\text { Representatives }\end{array}$ & 297 & 209 \\
\hline $\begin{array}{l}\text { Yogyakarta's House of } \\
\text { Representatives }\end{array}$ & 39 & 189 \\
\hline Total & 688 & 571 \\
\hline
\end{tabular}

Source: Processed data, 2019

This study follows (Lewis, Zamith, \& Hermida, 2013) which combines automatic data collection and manual coding. This study utilizes the Nvivo application with the Ncapture feature to retrieve data from a Facebook page and Twitter account. Ncapture is a browser extension developed by the QSR to capture web content and social media data. Data coding and analysis was conducted using Microsoft Excel.

As previously states, this study aims to identify concepts or categories in local parliamentary communication on Facebook and Twitter using an analytical generalization approach (Yin, 2014, p. 199). The collected data is then interpreted using a content analysis approach (Lewis et al., 2013). The following step is to group posts/tweets into certain categories. This study utilizes a preliminary list of categories developed from the research of (Leston-Bandeira \& Bender, 2013) which formulates several categories. The list is gradually modified and expanded inductively by regarding the categories and data. Categories and examples can be seen in Table 2 .

\section{Data Analysis}

Next, coding and analysis are conducted in three stages. The first stage is the coding conducted by the first author using the initial category and then modifying it. The second stage is the second encoding which is intended to ensure reliability. The third stage is coding activities conducted by an additional assistant who is not affiliated with this research. Searching for official social media accounts is conducted by visiting the official websites of each local parliament to find direct links to official social media accounts. If social media is not included in the official website, searches are conducted directly on each social media.

\section{Results}

The Banten's House of Representative's social media is managed by the DPRD Secretariat in the Aspiration and Public Relations Section. The Aspiration and Public Relations section consist of Coverage and Protocol Sub-Section, Information and Publication Sub-Section, and Community Fraction and Aspiration Sub-Section. Meanwhile, the management of social media in the DKI Jakarta's House of Representatives is conducted by the sub-section on Documentation and Public Relations which is under the Legislation and Public Relations section. Then, in West Java Province, social media is managed by the Public Relations and Protocol Section in the Publication and Information Sub-Section. Last, the management of social media in the Yogyakarta's House of Representative is conducted by the Public Relations Sub-Section under the Public Relations and Protocol Section. 
Table 2.

Post Categories and Examples

\begin{tabular}{|c|c|c|}
\hline No & Category & Post/Tweet Example \\
\hline 1 & $\begin{array}{l}\text { Offline parliament } \\
\text { advocacy }\end{array}$ & $\begin{array}{l}\text { Commission B encourages Food Security, Marine, and Agriculture Services to } \\
\text { intensify the supervision of fertilizers, seeds, and pesticides for traders, retailers, } \\
\text { distributors, and producers in the DKI Jakarta area. http:// dprd-dkijakartaprov.go.id/ } \\
\text { komisi-b-ingin - pembinaan-pengawasan-pupuk-benih-dan-pestisida-digencarkan/ } \\
\text {... \#DPRDDKIJakarta \#DPRDDKI \#DKIJakarta \#Jakarta pic.twitter.com/tGLQtQhdi5 }\end{array}$ \\
\hline 2 & $\begin{array}{l}\text { Congratulatory } \\
\text { message }\end{array}$ & $\begin{array}{l}\text { Congratulations on Commemorating } 188 \text { years of Gunungkidul Regency Anniversary } \\
\text { "SEMPULUR: Tumangkar, Ngrembaka, Lestari" @PemkabGK \#Gunungkidulku188 } \\
\text { \#DPRDDIY \#Jogja pic.twitter.com/3uPpI2sabm }\end{array}$ \\
\hline 3 & $\begin{array}{l}\text { Requesting citizens' } \\
\text { information }\end{array}$ & How were the speakers respond to the Banten Parliament TV show? \\
\hline 4 & Greeting & $\begin{array}{l}\text { In this most missed city, the morning greets you warmly. Good morning \#BlessedFriday } \\
\text { parliament's friends. Always spread a positive aura and good news. pic.twitter.com/ } \\
\text { opl7qWZrXh }\end{array}$ \\
\hline 5 & Educating citizen & $\begin{array}{l}\text { Please pay attention to the information regarding the Establishment of ASN, TNI, and } \\
\text { Polri's Working Hours during the month of Ramadan based on a form letter from } \\
\text { the Minister of State Apparatus Empowerment And Bureaucratic Reform. Sumber: @ } \\
\text { humas_jogja pic.twitter.com/yBtRjmtgbe }\end{array}$ \\
\hline 6 & Online assembly & $\begin{array}{l}\text { A Special Plenary Meeting is ongoing in the Submission of the Audit Report of the } \\
\text { Republic of Indonesia Supreme Audit Agency on the Financial Statements of the Banten } \\
\text { Provincial Government in Fiscal Year of } 2018 \text { in the Building of Banten's House of } \\
\text { Representatives Wednesday, } \\
(22 / 05 / 2019) \text {. \#dprdbanten \#bantenparlementv pic.twitter.com/YtKRptdLJt }\end{array}$ \\
\hline 7 & Promoting program & $\begin{array}{l}\text { Coming Soon “BINCANG PARLEMEN" Hallo Parliament Friends... Don't miss it! A } \\
\text { discussion with the stakeholders in Banten Province on the "Bincang Parlemen" on } \\
\text { Banten Parlemen TV's YouTube Channel. \#banten \#dprdbanten \#bantenparlementv } \\
\text { \#infoparlemen \#bincangparlemen pic.twitter.com/R7f7CgQNcg" }\end{array}$ \\
\hline 8 & $\begin{array}{l}\text { Parliamentary activity } \\
\text { report }\end{array}$ & $\begin{array}{l}\text { Commission II of West Java Province's House of Representatives Conducts a Working } \\
\text { Visit to the Southern Region of the Brackish Water and Sea Fisheries UPTD in the } \\
\text { Pangandaran Regency. Thursday (23/5/19) \#dprdjabar \#dprdjawabarat \#legislatifjabar } \\
\text { \#wakilrakyat \#jawabarat }\end{array}$ \\
\hline
\end{tabular}

Source: Processed data, 2019

This study aims to explore the use of social media by 4 Provincial House of Representatives in Indonesia. Before presenting the research findings, first, the authors present social media profiles from each account. Table 3 presents Likers and Followers. Facebook provides an option for users to like, follow or both. The difference is that if an account likes a page then the account automatically follows the page. Moreover, the preferred page posting will appear in the account feed and the account is listed in the "likes" directory. Users who follow an account may still see the preferred page posts but not listed in the "likes" directory.

Form likers and followers, the West Java's House of Representatives is the DPRD with the most likes and followers with 3,707 likers and 3,360 followers. A little below the account of West Java's House of Representatives is the Banten's House of Representatives with a number of likers and followers of 2,053 and 2,074 respectively. Meanwhile, the DKI Jakarta has 1,783 likers and 1,860 followers as the third rank in this study. The last is the DIY's account with 689 likers and 712 followers.

Then, table 4 presents the Twitter profile of the four accounts of House of Representatives consisting of account names, dates of joining, tweets, following, followers, and likes. Tweets contain the number of tweets generated by an account. Following is Twitter accounts followed while the follower is an account which follows the account. Likes are tweets which are liked by the account. 
Table 3.

Facebook Profiles

\begin{tabular}{clccc}
\hline \multirow{2}{*}{ No } & \multicolumn{2}{c}{ Name } & \multirow{2}{*}{ Account's Name } & \multicolumn{2}{c}{ Facebook Account } \\
\cline { 3 - 5 } & & Likers & Followers \\
\hline 1 & Provincial Banten's House of Representatives & DPRD Banten & 2,053 & 2,074 \\
2 & DKI Jakarta's House of Representatives & DPRD Provinsi DKI Jakarta & 1,783 & 1,860 \\
3 & West Java's House of Representatives & DPRD Jawa Barat & 3,707 & 3,360 \\
4 & DIY's House of Representatives & Humas DPRD DIY & 698 & 712 \\
\hline
\end{tabular}

Source: Processed data, 2019

Table 4.

Twitter Profiles

\begin{tabular}{|c|c|c|c|c|c|c|c|}
\hline \multirow{2}{*}{ No } & \multirow{2}{*}{ Name } & \multirow{2}{*}{ Account } & \multirow{2}{*}{ Date Joined } & \multicolumn{4}{|c|}{ Twitter Account } \\
\hline & & & & Tweet & Following & Followers & Likes \\
\hline 1 & $\begin{array}{l}\text { Banten's House of } \\
\text { Representatives }\end{array}$ & @DPRDBANTEN & December 2016 & 205 & 25 & 51 & 13 \\
\hline 2 & $\begin{array}{l}\text { DKI Jakarta's House of } \\
\text { Representatives }\end{array}$ & $@$ @prddki & May 2010 & 1,436 & 1 & 783 & 5 \\
\hline 3 & $\begin{array}{l}\text { West Java's House of } \\
\text { Representatives }\end{array}$ & @HUMASDPRD & May 2014 & 10,319 & 2.647 & 10,256 & 5,565 \\
\hline 4 & $\begin{array}{l}\text { DIY's House of } \\
\text { Representatives }\end{array}$ & @humasdprddiy & February 2018 & 901 & 240 & 601 & 174 \\
\hline
\end{tabular}

Source: Processed data, 2019

Overall, the Provincial West Java's House of Representatives is the account with the most tweets, following, followers, and likes in this study. Followed by the DKI Jakarta's House of Representatives and DIY's House of Representatives. The last is the Banten's House of Representatives. The account which was first created was the DKI Jakarta's account and was followed by the West Java's House of Representatives two years later. The youngest account is the DIY's account.

Except for the West Java's account, the rest of the accounts are more active on Facebook than Twitter. On Facebook, the two most active accounts are the Banten and West Java's House of Representatives. On Twitter, the most active account in the West Java and DKI Jakarta's House of Representatives.

On Facebook, the Banten's account uses more of its account to broadcast live hearings, promote parliament programs, and provide information on parliamentary activities, accounting for $24 \%$ for each category. Moreover, $17 \%$ of the congratulatory message was found in the Banten's account. Banten Province does not use much of its Facebook account to greet followers and request information from the public. The unavailable content on Banten's Facebook account is offline parliament advocacy and public education.

The Facebook account of the DKI Jakarta's House of Representatives is more on distributing offline parliamentary advocacy information as much as $32 \%$. Facebook's use of reporting on parliamentary activities for $21 \%$. The DKI Jakarta's Facebook is rarely used to post a congratulatory message. The DKI Jakarta's House of Representatives does not use its Facebook to request information from the community, greet followers, provide education, broadcast online hearings and promote programs.

Moreover, $57 \%$ of the content on West Java's Facebook page contains reports on the House of Representatives activities. Followed by offline parliament advocacy for 33\%. Messages which are rarely found are congratulatory messages and educative information messages. 
Table 5.

Content Category on Facebook

\begin{tabular}{clcccc}
\hline No & \multicolumn{1}{c}{ Category } & $\begin{array}{c}\text { Banten's } \\
\text { DPRD }\end{array}$ & $\begin{array}{c}\text { DKI Jakarta's } \\
\text { DPRD }\end{array}$ & $\begin{array}{c}\text { West Java's } \\
\text { DPRD }\end{array}$ & $\begin{array}{c}\text { DIY's } \\
\text { DPRD }\end{array}$ \\
\hline 1. & Offline parliament advocacy & $0 \%$ & $32 \%$ & $33 \%$ & $7 \%$ \\
2. & Congratulatory message & $17 \%$ & $6 \%$ & $8 \%$ & $8 \%$ \\
3. & Requesting citizens' information & $3 \%$ & $0 \%$ & $0 \%$ & $0 \%$ \\
4. & Greeting & $7 \%$ & $0 \%$ & $0 \%$ & $7 \%$ \\
5. & Educating citizen & $0 \%$ & $0 \%$ & $1 \%$ & $17 \%$ \\
6. & Online assembly & $24 \%$ & $0 \%$ & $0 \%$ & $0 \%$ \\
7. & Promoting program & $24 \%$ & $0 \%$ & $0 \%$ & $23 \%$ \\
8. & Parliamentary activity report & $24 \%$ & $21 \%$ & $57 \%$ & $37 \%$ \\
\hline
\end{tabular}

Source: Processed data, 2019

Table 6.

Content Category on Twitter

\begin{tabular}{clcccc}
\hline No & \multicolumn{1}{c}{ Category } & $\begin{array}{c}\text { Banten's } \\
\text { DPRD }\end{array}$ & $\begin{array}{c}\text { DKI Jakarta's } \\
\text { DPRD }\end{array}$ & $\begin{array}{c}\text { West Java's } \\
\text { DPRD }\end{array}$ & DIY's DPRD \\
\hline 1. & Offline parliament advocacy & $1 \%$ & $55 \%$ & $61 \%$ & $12 \%$ \\
2. & Congratulatory message & $4 \%$ & $7 \%$ & $3 \%$ & $5 \%$ \\
3. & Requesting citizens' information & $6 \%$ & $0 \%$ & $0 \%$ & $0 \%$ \\
4. & Greeting & $1 \%$ & $0 \%$ & $0 \%$ & $1 \%$ \\
5. & Educating citizen & $2 \%$ & $0 \%$ & $4 \%$ & $10 \%$ \\
6. & Online assembly & $15 \%$ & $0 \%$ & $0 \%$ & $1 \%$ \\
7. & Promoting program & $11 \%$ & $0 \%$ & $0 \%$ & $21 \%$ \\
8. & Parliamentary activity report & $59 \%$ & $37 \%$ & $31 \%$ & $50 \%$ \\
\hline
\end{tabular}

Source: Processed data, 2019

Types of information which are not found such as information request to the public, greet followers, broadcast online hearings, and promote programs.

Last, DKI Jakarta's House of Representatives is using Facebook more to provide parliamentary activity reports with $37 \%$. Followed by contents to promote its program and educate the community with $23 \%$ and $17 \%$ respectively. The type of information rarely given by this account is offline parliament advocacy, congratulatory messages, and greetings. The type of information which is not found in this account is requesting information from citizen and online assembly.

Table 6 shows the categories of content on the provincial House of representatives Twitter accounts in all four research locations. On Twitter, Banten's House of Representatives shares a lot of information on the parliamentary activities with $59 \%$. Content which broadcasts online hearings and promotes program is found to be $15 \%$ and $11 \%$ respectively. Moreover, content which is rarely shared is offline parliamentary advocacy, congratulatory message, request for information from the community, greeting, and public education.

For the DKI Jakarta's account, it tweets contain about offline parliamentary advocacy for $55 \%$. Moreover, the most frequently found information is news about parliamentary activities which is about $37 \%$. Tweets containing the congratulatory message are at $7 \%$. The DKI Jakarta's account does not share request for the public's information, greeting, public education, online assembly, and program promotion.

Similar to the DKI Jakarta's account, the West Java's House of Representatives shares 
more information about the offline parliament advocacy (61\%), followed by the parliamentary activity report (31\%). The information which is rarely shared his congratulatory message and public education. The West Java's DPRD never shared information such as requesting information from the public, greeting, online assembly and promoting the program.

The DIY's House of Representatives shares more information about the parliament activities (50\%) on Twitter. Moreover, tweets for program promotion, offline policy advocacy, and educating people are $21 \%, 12 \%$, and $10 \%$ respectively. The rarely shared content on Twitter is the congratulatory message, greeting, and online hearings. The DIY's House of Representatives does not use its account to request information from the community.

\section{Discussion}

This study aims to examine the presence of local parliamentary institutions on social media which is Facebook and Twitter. This study generally found that social media is a direct channel of communication between local parliaments and community. This study also found three types of images of local parliaments in utilizing Twitter and Facebook. The first type is the Banten's House of Representatives. This account is willing to use social media to provide information about online assembly. Banten's House of Representatives, compared to other local parliaments, bravely published the online legislative assembly. Thus, the public can observe the ongoing legislative assembly and this promotes openness. For this reason, we named it as "performer".

Then, DKI Jakarta's and West Java's House of Representatives have similar social media profiles. They more often publish information about parliamentary advocacy offline and reports on parliamentary activity. Both treat social media similar to their website. Information from the website is republished on social media without adjusting, for example by creating infographics. These reasons encourage authors to embrace the title of "reporter".

DIY"s House of Representatives published informative and educational information to the public. Two prominent categories that are not commonly found in other social media profiles are the use of social media to educate the public and promote programs. This means that the account uses social media to market government programs which are then the type of "marketer" suitable to be embedded in this profile.

Different from previous studies which found that communication between parliament and society usually one direction (HalevaAmir, 2011; Ross \& Bürger, 2014), This research showed that local parliamentarians not only use social media to communicate two-way, but also obtain and react to community feedback in their social media. This study also proves that social media is present to improve the quality of parliamentary relations with the community, one of which is by broadcasting online hearings found in the Banten and DIY's House of Representatives.

Previous studies have found that parliamentary presence on social media will make people feel close and then it will enhance trust (Lee \& Shin, 2012). This study found that by using various methods such as sharing the information which was educating, giving congratulatory, and greeting the people, the community would ultimately believe in the performance of the local parliament.

Associated with the research findings that the DKI Jakarta and Jawa Barat's House of Representatives only use their social media to share information about parliamentary activities, there are several answers to why an organization's social media adoption is considered a failure or half-heartedly managed. Omar, Stockdale, \& Scheepers (2014) discovered that the failure or slow implementation of technology such as social media such as absence of resources like ICT 
abilities, time, expenses and understanding lead to failures. The study found that there is a need to develop social media strategies because parliamentarians tend to have a more older age than employees who work in the council's office. The role of board members in this regard is to drive strategic initiatives so that their knowledge of social media will influence the ability of the board to adopt social media.

This paper conforms to the results of Chun et al. (2010) who found that the realization of broad benefits obtained by organizations which effectively use social media has not been achieved because organizations tend to use social media for information dissemination only. The absence of the social media uses for twoway communication and the development of social media platforms for innovative activities by the government sue to concerns about values, beliefs, resources, and risks (Omar et al., 2014). The existing literature is still limited to the fact that the government uses social media as an interactive two-way communication tool (Reddick et al., 2017), while this study finds that social media is utilized by the government primarily to provide information to the citizens rather than interacting with them. this study is also in line with findings (Hand \& Ching, 2011) which discovered that the government refused to provide control to the community and in several instances the government even filtered and shaped the material because of an imbalance in interaction between the government and the community.

However, the use of social media is still in its initial stages. Moreover, the government has an awareness of the need to engage with citizens through social media and start experimenting and exploring the potential of social media (Omar et al., 2014). The high level of social media use found in this study is an indication that there is greater interest in interactive technology, moving beyond the status quo towards greater community involvement (Joshi \& Rosenfield, 2013; Leston-Bandeira
\& Bender, 2013) and the potential for more strategic planning for more sustainable use. Local parliaments must therefore formulate and execute policies to determine why social media is adopted, how interaction is managed, and how resources, time and other conditions are managed.

\section{Conclusions}

In general, local parliaments have tried to utilize social media to encourage openness which has been questioned by academics and practitioners. In this regards, several local parliamentary social media accounts have tried to use social media features such as sharing hearing videos live and online. Another function found in local parliamentary social media accounts is program promotion. Local parliaments use social media to market their programs to gain more community participation. To attract more community involvement, the local parliament tries to share educative information, give a congratulatory message, and greet its followers.

Unfortunately, although some parliaments have used social media to promote openness such as online legislative assemblies. Domination of republished content from the website without making adjustments is still often found. In addition, the institution's willingness to publicly publish legislative assembly is only found in one of the four observed accounts. Finally, features on social media are not maximally used, for example live and story features. These facts lead the authors to the conclusion that social media is still used half-heartedly.

Unfortunately, there are still variations in the adoption of social media by local parliamentary accounts. There are also local parliaments which still manage their accounts as websites. They only share the information which is the same as the one on the website. Moreover, there is no special treatment to maintain social media to increase public 
engagement for a more open, responsive, and transparent parliament's image. Therefore, in addition to the important role of leaders' political will to open information and use social media as it should be, technical positions for social media officers need to be developed to properly manage the social media.

Even though the researchers have tried their best to conduct the research, there are several weaknesses in this study. First, the time used is only for three months. For future research, to gain a more complete picture of the use of social media, it may take a longer time of research, for example, a year. Moreover, this study only chose four research locations so that further study may add more accounts to be observed to find new types. Finally, the data in this study are only obtained from social media, further research may be conducted by combining it with interviews and other data collection methods.

\section{References}

Aldrich, D. P., \& Ono, Y. (2016). Local politicians as linking social capital: an empirical test of political behavior after Japan's 3/11 disasters. Natural Hazards, 84(3), 1637 1659. doi: 10.1007/s11069-016-2503-x

Ambardi, K., Purbokusumo, Y., Daryanti, S., Kustiningsih, W., Rahyaputra, V., Yurista, H. P., ... Kusumaningtyas, A. P. (2017). The ICT Development Index Indonesia. In P. S. Winanti \& B. Kusumasari (Eds.), Proceedubf Research Days FISIPOL UGM 2017 "Knowledge for Better Society" (pp. 1317). Yogyakarta: Sekretariat Hibah Riset, Publikasi, dan Pengabdian Masyarakat Faculty of Social and Political Sciences Universitas Gadjah Mada.

Anderson, P. J., \& Mcleod, A. (2004). The great non-communicator? The mass communication deficit of the European parliament and its press directorate* JCMS: Journal of Common Market Studies, 42(5), 897-917. doi: 10.1111/j.0021- 9886.2004.00534.x

Arnstein, S. R. (1969). A ladder of citizen participation. Journal of the American Institute of Planners, 35(4), 216-224. doi: 10.1080/01944366908977225

Avery, E. J., \& Graham, M. W. (2013). Political public relations and the promotion of participatory, transparent government through social media. International Journal of Strategic Communication, 7(4), 274-291. doi: 10.1080/1553118X.2013.824885

Bertot, J. C., Jaeger, P. T., \& Grimes, J. M. (2010). Using ICTs to create a culture of transparency: E-government and social media as openness and anti-corruption tools for societies. Government Information Quarterly, 27(3), 264-271. http://doi. org/10.1016/j.giq.2010.03.001

Bertot, J. C., Jaeger, P. T., \& Hansen, D. (2012). The impact of polices on government social media usage : Issues, challenges, and recommendations. Government Information Quarterly, 29(1), 30-40. doi: 10.1016/j.giq.2011.04.004

Bolívar, M. P. R. (2016). Designing social media policy for local governments: opportunities and challenges. In M. Z. Sobaci (Ed.), Social media and local governments: Theory and Practice (pp. 37-58). Switzerland: Springer US. doi: 10.1007/978-3-319-17722-9

Bonsón, E., Torres, L., Royo, S., \& Flores, F. (2012). Local e-government 2.0 : Social media and corporate transparency in municipalities. Government Information Quarterly, 29(2), 123-132. doi: 10.1016/j. giq.2011.10.001

Brummette, J., DiStaso, M., Vafeiadis, M., \& Messner, M. (2018). Read all about it: The politicization of "Fake News" on twitter. Journalism and Mass Communication Quarterly, 95(2), 497-517. doi: $10.1177 / 1077699018769906$

Carman, C. (2010). The process is the reality: Perceptions of procedural fairness 
and participatory democracy. Political Studies, 58(4), 731-751. doi: 10.1111/j.14679248.2010.00840.x

Chun, S. A., Shulman, S., Sandoval, R., \& Hovy, E. (2010). Government 2.0: Making connections between citizens, data and government. Information Polity, 15(1-2), 1-9. doi: 10.3233/IP-2010-0205

Curtin, D., \& Meijer, A. J. (2006). Does transparency strengthen legitimacy?. Information Polity, 11(2), 109-122. doi: 10.3233/IP-2006-0091

di Gennaro, C. (2006). The internet and the public: Online and offline political participation in the United Kingdom. Parliamentary Affairs, 59(2), 299-313. http:// doi.org/10.1093/pa/gs1004

Doro, E., \& Kufakurinani, U. (2018). Resource curse or governance deficit? The role of parliament in Uganda's oil and Zimbabwe's diamonds. Journal of Southern African Studies, 44(1), 43-57. doi: 10.1080/03057070.2018.1403214

Ellison, N., \& Hardey, M. (2014a). Social media and local government: Citizenship, consumption and democracy. Local Government Studies, 40(1), 21-40. doi: 10.1080/03003930.2013.799066

Ellison, N., \& Hardey, M. (2014b). Social media and local government: Citizenship, consumption and democracy. Local Government Studies, 40(1), 21-40. doi: 10.1080/03003930.2013.799066

Fan, xiaoling H. D. Z. Q. Z. W. (2016). How to strengthen the social media interactivity of e-government: Evidence from China. Online Information Review, 40(1), 79-96. doi: 10.1108/09574090910954864

Firmstone, J., \& Coleman, S. (2015). Public engagement in local government: the voice and influence of citizens in online communicative spaces. Information, Communication \& Society, 18(6), 680-695. doi: 10.1080/1369118X.2014.986180
Francoli, M., \& Ward, S. (2008). 21st century soapboxes? MPs and their blogs. Information Polity, 13(1-2), 21-39. doi: 10.3233/IP-2008-0143

Grissom, J. A., \& Harrington, J. R. (2013). Local legislative professionalism. American Politics Research, 41(1), 76-98. doi: 10.1177/1532673X12448212

Gulati, G. J., \& Williams, C. B. (2013). Social media and campaign 2012. Social Science Computer Review, 31(5), 577-588. doi: 10.1177/0894439313489258

Haleva-Amir, S. (2011). Online Israeli politics: the current state of the art. Israel Affairs, 17(3), 467-485. doi: 10.1080/13537121.2011.584678

Hand, L. C., \& Ching, B. D. (2011). "You Have One Friend Request" an exploration of power and citizen engagement in local governments' use of social media. Administrative Theory \& Praxis, 33(3), 362 382. doi: 10.2753/ATP1084-1806330303

Hartz-Karp, J., \& Briand, M. K. (2009). Institutionalizing deliberative democracy. Journal of Public Affairs, 9(2), 125-141. doi: 10.1002/pa.320

Hazell, R., Bourke, G., \& Worthy, B. (2012). Open house? Freedom of information and its impact on The UK Parliament. Public Administration, 90(4), 901-921. doi: 10.1111/j.1467-9299.2012.02024.x

Heaselgrave, F., \& Simmons, P. (2016). Culture, competency and policy: Why social media dialogue is limited in Australian local government. Journal of Communication Management, 20(2), 133-147. doi: 10.1108/ JCOM-07-2015-0059

Holmberg, S., Lindberg, S., \& Svensson, R. (2017). Trust in parliament. Journal of Public Affairs, 17(1-2), e1647. doi: 10.1002/ pa.1647

Holmberg, S., \& Rothstein, B. (2017). Trusting other people. Journal of Public Affairs, 17(1-2), e1645. doi: 10.1002/pa.1645 
Hudaya, M., Smark, C., Watts, T., \& Silaen, P. (2015). The use of accountability reports and the accountability forum: Evidence from an Indonesian local government. Australasian Accounting, Business and Finance Journal, 9(4), 57-70. doi: 10.14453/ aabfj.v9i4.5

Inman, J., \& Inman, J. (2012). 4 - devolved parliament and assemblies and regional government. In Finding Official British Information (pp. 103-144). doi: 10.1016/ B978-1-84334-392-9.50004-5

Joshi, D., \& Rosenfield, E. (2013). MP transparency, communication links and social media: A comparative assessment of 184 parliamentary websites. The Journal of Legislative Studies, 19(4), 526-545. doi: 10.1080/13572334.2013.811940

Kaplan, A. M., \& Haenlein, M. (2010). Users of the world, unite! The challenges and opportunities of social media. Business Horizons, 53, 59-68. doi: 10.1016/j. bushor.2009.09.003

Lee, E.-J., \& Shin, S. Y. (2012). Are they talking to me? Cognitive and affective effects of interactivity in politicians' twitter communication. Cyberpsychology, Behavior, and Social Networking, 15(10), 515-520. doi: 10.1089/cyber.2012.0228

Leston-Bandeira, C. (2009). The impact of the internet on parliaments: A legislative studies framework. Parliamentary Affairs, 4. doi: $10.1093 / \mathrm{pa} / \mathrm{gsm} 040$

Leston-Bandeira, C., \& Bender, D. (2013). How deeply are parliaments engaging on social media. Information Polity, 18(4), 281-297. doi: 10.3233/IP-130316

Lewis, S. C., Zamith, R., \& Hermida, A. (2013). Content analysis in an era of big data: A hybrid approach to computational and manual methods. Journal of Broadcasting $\mathcal{E}$ Electronic Media, 57(1), 34-52. doi: 10.1080/08838151.2012.761702

Lindner, R., \& Riehm, U. (2011). Broadening participation through e-petitions? An empirical study of petitions to the German parliament. Policy E Internet, 3(1), 63-85. doi: 10.2202/1944-2866.1083

Lusoli, W., Ward, S., \& Gibson, R. (2005). (Re) connecting politics? Parliament, the public and the internet. Parliamentary Affairs, 59(1), 24-42. doi: 10.1093/pa/gsj010 Macintosh, A., Adams, N., Whyte, A., \& Johnston, J. (2008). Epetitioning in the scottish parliament. In H. Chen, L. Brandt, V. Gregg, R. Traunmuller, S. Dawes, E. Hovy, A. Macintosh, C. A. Larson (Eds.), Digital Goverenment (pp. 487-501). Boston, MA: Springer.

Majumdar, S. R. (2017). The case of public involvement in transportation planning using social media. Case Studies on Transport Policy, 5(1), 121-133. doi: 10.1016/j.cstp.2016.11.002

Missingham, R. (2011). E-parliament: Opening the door. Government Information Quarterly, 28(3), 426-434. doi: 10.1016/J. GIQ.2010.08.006

Mossberger, K., Wu, Y., \& Crawford, J. (2013). Connecting citizens and local governments? Social media and interactivity in major U.S. cities. Government Information Quarterly, 30(4), 351-358. doi: 10.1016/j.giq.2013.05.016

Nica, E., Popescu, G. H., Nicolaescu, E., \& Constantin, V. D. (2014). The effectiveness of social media implementation at local government levels. Transylvanian Review of Administrative Sciences, 2014(SI), 152-166.

Norris, D. F., \& Reddick, C. G. (2013). Local e-government in the United States: Transformation or incremental change?. Public Administration Review, 73(1), 165175. doi: 10.1111/j.1540-6210.2012.02647.x Norris, P. (2004). The evolution of election campaigns Pippa Norris the evolution of election campaigns: Eroding political engagement?. Cambridge: Pippa Norris.

Okura, S., \& Kaigo, M. (2016). Who leads advocacy through social media in Japan? 
Evidence from the "Tsukuba Civic Activities Cyber-Square" facebook page. Information (Switzerland), 7(4), 1-12. doi: 10.3390/info7040066

Omar, K., Stockdale, R., \& Scheepers, H. (2014). Social media use in local government: An Australian perspective. International Journal of Public Administration, 37(10), 666675. doi: 10.1080/01900692.2014.903270

Picazo-vela, S., Gutiérrez-martínez, I., \& Lunareyes, L. F. (2012). Understanding risks, benefits, and strategic alternatives of social media applications in the public sector. Government Information Quarterly, 29(4), 504-511. doi: 10.1016/j.giq.2012.07.002

Ranchordás, S. (2017). Digital agoras: democratic legitimacy, online participation and the case of Uber-petitions. The Theory and Practice of Legislation, 5(1), 31-54. doi: 10.1080/20508840.2017.1279431

Reddick, C. G., Chatfield, A. T., \& Ojo, A. (2017). A social media text analytics framework for double-loop learning for citizen-centric public services: A case study of a local government Facebook use. Government Information Quarterly, 34, 1-16. doi: 10.1016/j.giq.2016.11.001

Ross, K., \& Bürger, T. (2014). Face to face(book): Social media, political campaigning and the unbearable lightness of being there. Political Science, 66(1), 46-62. doi: $10.1177 / 0032318714534106$

Sæbø, Ø., Flak, L. S., \& Sein, M. K. (2011). Understanding the dynamics in
e-Participation initiatives: Looking through the genre and stakeholder lenses. Government Information Quarterly, 28(3), 416-425. doi: 10.1016/j.giq.2010.10.005

Santoso, A. D. (2019). Social media campaigns on disability awareness: A content analysis of official government Twitter accounts. Life Span and Disability, 22(I), 95-112.

Scott, J. K. (2006). “E” the People: Do U.S. Municipal government web sites support public involvement?. Public Administration Review, 66(3), 341-353. doi:10.1111/j.15406210.2006.00593.x

Sobaci, M. Z., \& Karkin, N. (2013). The use of twitter by mayors in Turkey: Tweets for better public services?. Government Information Quarterly, 30(4), 417-425. doi: 10.1016/j.giq.2013.05.014

Swigger, N. (2017). The online citizen: Is social media changing citizens' beliefs about democratic values?. Polictical Behaviour, 35(3), 589-603.

Tomsa, D. (2014). Party system fragmentation in Indonesia: The subnational dimension. Journal of East Asian Studies, 14(2), 249-278. doi: 10.1017/S1598240800008924

Williamson, W., \& Ruming, K. (2017). Urban consolidation process and discourses in Sydney: unpacking social media use in a community groups media campaign. Planning Theory \& Practice, 9357(June), 1-18. doi: 10.1080/14649357.2017.1328768

Yin, R. K. (2014). Cast study research: Design and methods. London: Sage. 